\title{
A new species of Procambarus (Decapoda, Cambaridae) from the State of Querétaro, Mexico
}

\author{
Carlos Pedraza-Lara', Pedro Joaquín Gutiérrez-Yurrita², \\ Vladimir Salvador De Jesus-Bonilla'
}

I Ciencia Forense, Facultad de Medicina, Universidad Nacional Autónoma de México, Circuito de la Investigación Científica s/n, Ciudad Universitaria, Coyoacán, México City, México 2 Instituto Politécnico NacionalCentro Interdisciplinario de Investigaciones y Estudios sobre Medio Ambiente y Desarrollo, México City, México

Corresponding author: Carlos Pedraza-Lara (pedrazal@gmail.com)

Academic editor: L. E. Bezerra | Received 11 August 2020 | Accepted 21 October 2020 | Published 6 July 2021

http://zoobank.org/B55DEC1A-6C1D-40CF-BB59-3BA3F84C3F6E

Citation: Pedraza-Lara C, Gutiérrez-Yurrita PJ, De Jesus-Bonilla VS (2021) A new species of Procambarus (Decapoda, Cambaridae) from the State of Querétaro, Mexico. ZooKeys 1048: 1-21. https://doi.org/10.3897/zookeys.1048.57493

\begin{abstract}
With a Nearctic distribution, the family Cambaridae harbors a high species richness in Mexico, which is also evident along the Pánuco River catchment. A series of surveys carried on in five populations from the Sierra Gorda Biosphere Reserve in the State of Querétaro resulted in localizing a putative new species for science. A molecular phylogenetic study and species delimitation analyses including all the known Procambarus species from the Pánuco River catchment were conducted based on three mitochondrial genes (16S rDNA, 12S rDNA, and COI; 2,462 bp in total). Phylogeny recovered all species as monophyletic, including the populations under study. All delimitation results based on barcoding, ABGD, GMYC, bPTP, and gonopod differentiation agree in the recognition of a new taxon, to which the name Procambarus xihui sp. nov. is given, and its diagnosis and description are provided. The new species can be distinguished from the remaining species in the genus, among other characters, by a unique configuration of the terminal elements of the first pleopod of form I male, which includes a central projection lamellate, hood-like, forming a concave blade-like structure mesially directed, as well as a caudal process crest-like, mesiodistally directed, forming a lateral side of the concavity.
\end{abstract}

\section{Keywords}

Astacidea, Crayfish, integrative taxonomy, species delimitation, systematics

Copyright Carlos Pedraza-Lara et al. This is an open access article distributed under the terms of the Creative Commons Attribution License (CC BY 4.0), which permits unrestricted use, distribution, and reproduction in any medium, provided the original author and source are credited. 


\section{Introduction}

The genus Procambarus Ortmann, 1905 encompass 45 native species and subspecies occurring in Mexico, inhabiting both Atlantic and Pacific coasts. An important part of the species richness in Mexico inhabits the Pánuco water basin, along the Sierra Madre Oriental and north of the Trans Mexican Volcanic Belt. To date, seven species have been recorded from that region: Procambarus cuevachicae (Hobbs, 1941), P. hidalgoensis López-Mejía, Álvarez \& Mejía-Ortíz, 2005, P. roberti Villalobos \& Hobbs, 1974, P. strenthi Hobbs, 1977, P. toltecae Hobbs, 1943, P. villalobosi Hobbs, 1969, and P. xilitlae Hobbs \& Grubbs, 1982. In a survey of the diversity of the genus, previous studies located a series of populations from the aforementioned basin, in the Sierra Gorda Biosphere Reserve, at the northern side of the State of Querétaro, whose specific identity could not be confirmed (Gutiérrez-Yurrita et al. 2002). Analyses by the authors found a degree of morphological distinctiveness compared to other species of the genus from nearby regions while additional studies obtained the $16 \mathrm{~S} \mathrm{rDNA}$ gene from several of them. Later, a study using Random Amplification of Polymorphic DNA and morphological information agreed with the conclusion that several populations from the Sierra Gorda Biosphere Reserve could correspond to an undescribed species (Pedraza-Lara et al. 2004). It is necessary to verify such findings, and to formalize the taxonomic status of such populations (see Materials and methods). Consequently, this article aims to clarify this taxonomic situation using an integrative approach, including molecular markers commonly used for the delimitation of crayfish species in addition to traditional morphology.

\section{Materials and methods}

\section{Sampling}

A series of collections were made in the Sierra Gorda Biosphere Reserve (SGBR) for 20 years, beginning in 2002 (Table 1; Fig. 1). This study includes the following populations assigned to the new species from the counties Jalpan de Serra and Landa de Matamoros in the state of Querétaro: Arroyo Álamos, Arroyo Camelinas, Río Verdito, San Juanito and Saldiveña. All were sampled in 2002, 2007, and 2019 by the collectors mentioned in Systematics. For the localities of San Juanito and Saldiveña we failed to obtain any crayfish in 2019. Other populations sampled more than once were Palitla (2002, 2019), Media Luna (2007, 2015, 2019), Santa Anita spring (2012, 2018), and Xicotepec (two occasions in 2019). Specimens were collected by hand and identified using the available keys (Hobbs 1972a), original descriptions, and reviews (Hobbs 1941, 1943, 1977; Villalobos 1944, 1955, 1958; Villalobos-Figueroa 1954; Villalobos Figueroa and Hobbs 1974; López-Mejía et al. 2005). Details of the collection sites are provided in Table 1. Type material was deposited at the following Institutions: National Collection of Crustaceans, Institute of Biology, Universidad Nacional 


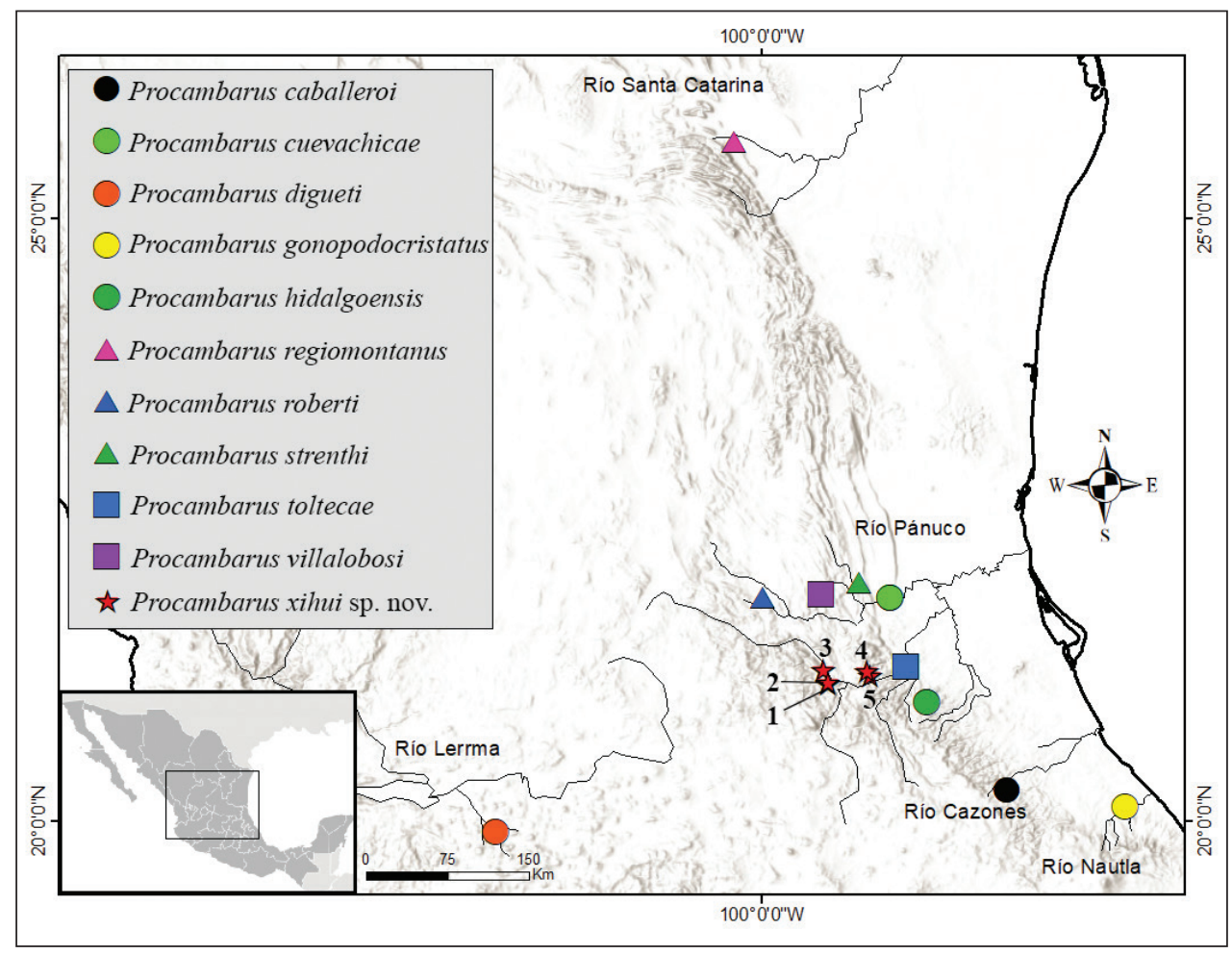

Figure I. Map of localities. Populations from SGBR are depicted as stars, and numbers correspond to the following sites: 1. Arroyo Los Álamos; 2. Arroyo Camelinas; 3. Saldiveña; 4. Río Verdito; 5. San Juanito.

Autónoma de México (CNCR); National Museum of Natural History, Smithsonian Institution, USA (NMNH) and Arthropod Collection of Forensic Reference at Forensic Program, UNAM, Mexico (CARF). The holotype (CNCR 35721), allotype (CNCR 35723), and morphotype (CNCR 35722) were deposited at CNCR. Paratype series (one male form I, and one female, under catalog number USNM 1638484 and USNM 1638485, respectively) were deposited at NMNH. Additional paratypes were deposited at CARF under catalog numbers CARF - CPLC45 - CARF - CPLC47. Measurements of the types are provided in Table 2.

Aiming to account for an accurate representation of Mexican species of Procambarus, except for the troglobitic Procambarus xilitlae, all the species previously assigned to the subgenus Ortmannicus (Hobbs 1972b) were included: P. acutus, P. caballeroi, P. cuevachicae, $P$. gonopodocristatus, $P$. hidalgoensis, $P$. toltecae, and $P$. villalobosi. In addition, $P$. digueti and $P$. regiomontanus were included as outgroups for phylogenetic analysis and reference in species delimitation (Table 1). Voucher numbers were assigned to all specimens and included in CARF (UNAM). Laboratory work was carried on in the Forensic Entomology Lab, Forensics Program, at UNAM.

Specimens were identified using the appropriate taxonomic keys (Hobbs 1972a; Bezerra et al. 2020), as well as the respective taxonomic descriptions. Measurements 
of type specimens were made on standard morphological characters used in crayfish taxonomy (Pedraza-Lara and Doadrio 2015). For paired characters, measurements were taken from the left side of the specimen with a digital caliper (Mitutoyo's Absolute Series 500, resolution: $0.01 \mathrm{~mm}$ ) and a stereoscopic microscope (Leica M60 APO). A validation procedure was done by measuring the same randomly chosen individuals three times. A Pearson correlation between replicates was done in which values above 0.8 were considered as indicatives of low measurement error. This was verified and all measurements, which showed values above 0.8 . Drawings from type series for description were prepared by direct observations using a caliper and a stereoscopic microscope (Leica M60 APOP) by Aslam Narvaez. Additionally, SEM pictures were taken from gonopods, epistome, and antennal scale of holotype, as well as annulus ventralis from allotype, at the Electronic Microscopy Laboratory, IBUNAM.

\section{Phylogenetic and species delimitation analysis}

Specimens were preserved in ethanol and a piece of abdominal muscle was taken for DNA purification, which was carried on using a phenol-chloroform protocol (Sambrook et al. 1989). Three mitochondrial genes were sequenced: $16 \mathrm{~S}$ rDNA (16S), $12 \mathrm{~S}$ rDNA (12S), and Cytochrome Oxidase subunit I (COI). These genes have accurate phylogenetic signal in crustaceans and are considered optimal choices to characterize the genetic variation and species delimitation in crustacean groups (Toon et al. 2009; Matzen da Silva et al. 2011; Pedraza-Lara et al. 2012). PCR amplifications using gene-specific primers were done using primers and following conditions previously standardized on cambarid species delimitation (Pedraza-Lara and Doadrio 2015) (see Table 3 for details on amplifications and genes analyzed). Amplifications were carried out in $10 \mathrm{~mL}$ reactions containing: $1 \mathrm{X}$ PCR buffer, $0.5 \mathrm{mM}$ of each primer, $0.2 \mathrm{mM}$ of each dNTP, $1.5 \mathrm{mM} \mathrm{MgCl}$, 1 U Platinum Taq polymerase (Thermo), and 10-50 ng of template DNA.

To investigate the species limits between the putatively undescribed taxon and other Procambarus species with molecular information we used the following approaches: genetic divergence of the barcoding COI gene (Hebert et al. 2003), the Automatic Barcode Gap Discovery (ABGD) (Puillandre et al. 2012), Bayesian Tree Poisson Process (bPTP) (Zhang et al. 2013), and the General Mixed Yule Coalescent model (GMYC) (Pons et al. 2006). Barcoding and ABGD analyses were carried using the COI gene; input for bPTP and GMYC was a concatenated matrix with the three mitochondrial markers.

The uncorrected $P$-distances and standard error of the COI marker between putative species were calculated in Mega 10.1.8, estimating standard error based on bootstrapping (Kumar et al. 2018). To determine the barcode gap, the ABGD analysis was run online (https://bioinfo.mnhn.fr/abi/public/abgd/abgdweb.html) setting the simple distance (relative gap width) to 0.5 , and default values for the remaining parameters.

For the GMYC approach, an ultrametric tree was reconstructed in Beast 2.6.2 (Bouckaert et al. 2014) using the GTR + $\Gamma+$ I model, a relaxed clock lognormal, and Yule model prior. Bayesian Markov chain Monte Carlo was run for 25 million 
generations, sampling trees every 1,000 generations. The log file was inspected in Tracer 1.7.1 (Rambaut et al. 2018) to confirm convergence and Effective Sample Size (ESS) $\geq 200$. A single maximum credibility tree was summarized with TreeAnnotator v2.6.2 after removing $15 \%$ of the trees as burn-in. The resulting tree was used as input to delimit species with the single threshold GMYC approach in the package 'splits' implemented in R (http://r-forge.r-project.org/projects/). The bPTP analysis was performed online (https://species.h-its.org/ptp/) using a ML phylogenetic tree as input (see below), the analysis was run 100,000 MCMC generations with burn-in of 15\%.

A phylogenetic hypothesis regarding the included specimens of Procambarus species was reconstructed with Maximum Likelihood (ML) and Bayesian Inference (BI) methods. These analyses were carried out to evaluate the congruence of the delimitation analyses previously mentioned with the formation of monophyletic clades at the terminals and evaluate its clade support. Conformation to monophylly is also another way to assist during taxon recognition (Rosen 1979; Donoghue 1985). The ML reconstruction was conducted in RAxML 8.2.12 (Stamatakis 2014) with a rapid bootstrap algorithm (-f a) with 1000 bootstrap replicates. For the BI method, the appropriate substitution model for each marker was inferred with Partition Finder 2 (Lanfear et al. 2017). The BI reconstruction was conducted in MrBayes 3.2.7a (Ronquist and Huelsenbeck 2003). We ran two runs with four MCMC chains with 50,000,000 generations, sampling every 1000 generations and setting a burn-in of $10 \%$. Convergence of chains and ESS (> 200) were confirmed in Tracer 1.7.1 (Rambaut et al. 2018).

It has been described that habitats in the SGBR face important threats like increasing drying (Mendoza-Villa et al. 2018), the cutting of forests, introduction of exotic species, destruction of habitat for agriculture and grazing, pollution of water and the alteration of river channels for human activities (Gutiérrez-Yurrita 2014). Considering this, an assessment of the extinction risk was done using the International Union for Conservation of Nature (IUCN) Red List of Threatened Species Categories and Criteria (IUCN Standards and Petitions Committee 2019). IUCN criteria were applied to the crayfish populations inhabiting the SGBR.

The data underpinning the analysis reported in this paper are deposited at GBIF, the Global Biodiversity Information Facility, and are available at https://doi. org/10.15468/3hu4bh.

\section{Results}

In all cases, morphological features were congruent and stable when several form I male specimens were available for one species. No issues were evident when separating and identifying species according to the literature. As usual in Procambarus, the morphology of the first pair of pleopods of male form I was useful to identify and distinguish the new species, as the structure of terminal elements was always congruent with what was originally described and allowed robust species identification. Accordingly, a series of unique traits were observed for the populations from the SGBR. 
Table I. Species, locality data, and GenBank accession numbers of specimens used in the phylogenetic and species delimitation analyses.

\begin{tabular}{|c|c|c|c|c|c|c|}
\hline \multirow[t]{2}{*}{ Species } & \multirow[t]{2}{*}{ Locality } & \multirow[t]{2}{*}{ Specimen } & \multirow{2}{*}{$\begin{array}{c}\text { Collection } \\
\text { year }\end{array}$} & \multicolumn{3}{|c|}{ GenBank accession numbers } \\
\hline & & & & $16 S$ & $12 S$ & $\operatorname{cox} 1$ \\
\hline \multirow[t]{6}{*}{$\begin{array}{l}\text { Procambarus xibui } \\
\text { sp. nov. }\end{array}$} & $\begin{array}{c}\text { Arroyo de Los Álamos, Yerbabuena, Jalpan de Serra, } \\
\text { Querétaro * }\end{array}$ & CPLC1 $1 \dagger$ & 2019 & MW280269 & MW280231 & MW266807 \\
\hline & $\begin{array}{c}\text { Arroyo de Los Álamos, Yerbabuena, Jalpan de Serra, } \\
\text { Querétaro * }\end{array}$ & CPLC23 $\ddagger$ & 2019 & MW280277 & MW280238 & MW266814 \\
\hline & Arroyo Camelinas, Yerbabuena, Querétaro & CPLC27 & 2002 & MW280280 & MW280242 & MW266816 \\
\hline & San Juanito, Landa de Matamoros, Querétaro & CPLC24 & 2002 & - & MW280239 & - \\
\hline & Río Verdito, Landa de Matamoros, Querétaro & CPLC25 & 2019 & MW280278 & MW280240 & - \\
\hline & Saldiveńa, Jalpan de Serra, Querétaro & CPLC26 & 2007 & MW280279 & MW280241 & MW266815 \\
\hline \multirow[t]{3}{*}{ P. toltecae } & Stream $1 \mathrm{Km}$ Soutwest of Palitla, San Luis Potosi* & CPLC3 & 2019 & MW280270 & MW280246 & MW266808 \\
\hline & Stream $1 \mathrm{Km}$ Soutwest of Palitla, San Luis Potosi ${ }^{*}$ & CPLC28 & 2019 & MW280281 & MW280243 & MW266817 \\
\hline & Huichihuayán, San Luis Potosi** & PopHui & 2012 & JX127823 & JX127687 & JX127966 \\
\hline \multirow[t]{2}{*}{ P. hidalgoensis } & Stream on driveway from Tlanchinol-Olotla, Hidalgo & CPLC5 & 2019 & MW280272 & MW280233 & MW266810 \\
\hline & Stream on driveway from Tlanchinol-Olotla, Hidalgo & CPLC29 & 2019 & MW280282 & MW280244 & - \\
\hline P. villalobosi & Cave East of Rayón, San Luis Potosi* & CPLC11 & 2019 & MW280274 & MW280235 & MW266812 \\
\hline P. villalobosi & Cave East of Rayón, San Luis Potosí & CPLC33 & 2019 & MW280285 & - & MW266820 \\
\hline P. & María de la Torre, Veracruz ${ }^{*}$ & CPLC30 & 2019 & MW280283 & - & MW266818 \\
\hline gonopodocristatus & María de la Torre, Veracruz* & CPL2474 & 2019 & MW280268 & MW280230 & - \\
\hline P. roberti & $\begin{array}{c}\text { Creek coming from La Media Luna, } 0.5 \mathrm{Km} \text { East, San } \\
\text { Luis Potosí* }\end{array}$ & CPLC13 & 2019 & MW280276 & MW280237 & - \\
\hline P. roberti & $\begin{array}{c}\text { Creek coming from La Media Luna, } 0.5 \text { Km East, San } \\
\text { Luis Potosí }\end{array}$ & CPLC32 & 2007 & MW280284 & MW280245 & MW266819 \\
\hline P. roberti & $-* * *$ & robertil & - & KX238070 & - & - \\
\hline \multirow[t]{2}{*}{ P. strenthi } & Santa Anita spring, San Luis Potosi* & CPLC10 & 2018 & MW280273 & MW280234 & MW266811 \\
\hline & $-{ }^{* * *}$ & strenthil & 2017 & KX238078 & - & - \\
\hline \multirow[t]{3}{*}{ P. caballeroi } & Stream southern of Xicotepec de Juárez, Puebla* & 2419 & 2019 & MW280265 & MW280226 & MW266803 \\
\hline & Stream southern of Xicotepec de Juárez, Puebla* & 2420 & 2019 & MW280266 & MW280227 & MW266804 \\
\hline & $-{ }^{* * *}$ & Pcb302 & - & KX238005 & - & - \\
\hline \multirow[t]{2}{*}{ P. cuevachicae } & La Cueva Chica, Ciudad Valles, San Luis Potosí & 2424 & 2020 & - & MW280228 & MW266805 \\
\hline & La Cueva Chica, Ciudad Valles, San Luis Potosí & 2425 & 2020 & MW280267 & MW280229 & MW266806 \\
\hline \multirow[t]{2}{*}{ P. acutus } & Canal en Ciudad Mante, Tamaulipas & 3952 & 2007 & MW280264 & - & MW266802 \\
\hline & Canal en Ciudad Mante, Tamaulipas** & PopMan & 2007 & JX127827 & - & JX127970 \\
\hline P. digueti & Camécuaro River, Michoacán & CPLC12 & 2012 & MW280275 & MW280236 & MW266813 \\
\hline \multirow[t]{2}{*}{ P. regiomontanus } & Guadalupe, Nuevo León & CPLC4 & 2018 & MW280271 & MW280232 & MW266809 \\
\hline & $* * *$ & DJ43 & 2018 & KX238068 & KX238138 & KX238224 \\
\hline
\end{tabular}

${ }^{*}$ Type locality; ${ }^{* *}$ from Pedraza-Lara et al. 2012; ${ }^{* * *}$ from Stern et al. 2017 ; † holotype; $\ddagger$ allotype.

\section{Species delimitation and phylogenetic analyses}

The following gene fragments were obtained: 16S (559 bps), 12S (397 bps), and COI (1506 bps), resulting in 2462 characters and giving a series of substitution models (Table 3). The resulting sequences were deposited in GenBank (Table 1), no signs of numts were found. The most variable fragment was $16 \mathrm{~S}$, followed by $12 \mathrm{~S}$ and COI (variable sites: $\mathrm{COI}=221 / 1506,16 \mathrm{~S}=169 / 55912 \mathrm{~S}=71 / 397)$; besides this, COI showed the highest proportion of parsimony-informative (PI) sites: $\mathrm{COI}=138,16 \mathrm{~S}=82,12 \mathrm{~S}=51$ (Table 3).

All delimitation analyses recovered a congruence between morphological identifications and molecular information for all species (Fig. 2; Suppl. material 1). The populations from SGBR are delimited as one distinct species according to all delimitation criteria, including the morphological observations carried on over specimens sampled. The COI genetic $P$-distance between all localities of the SGBR and the other species 

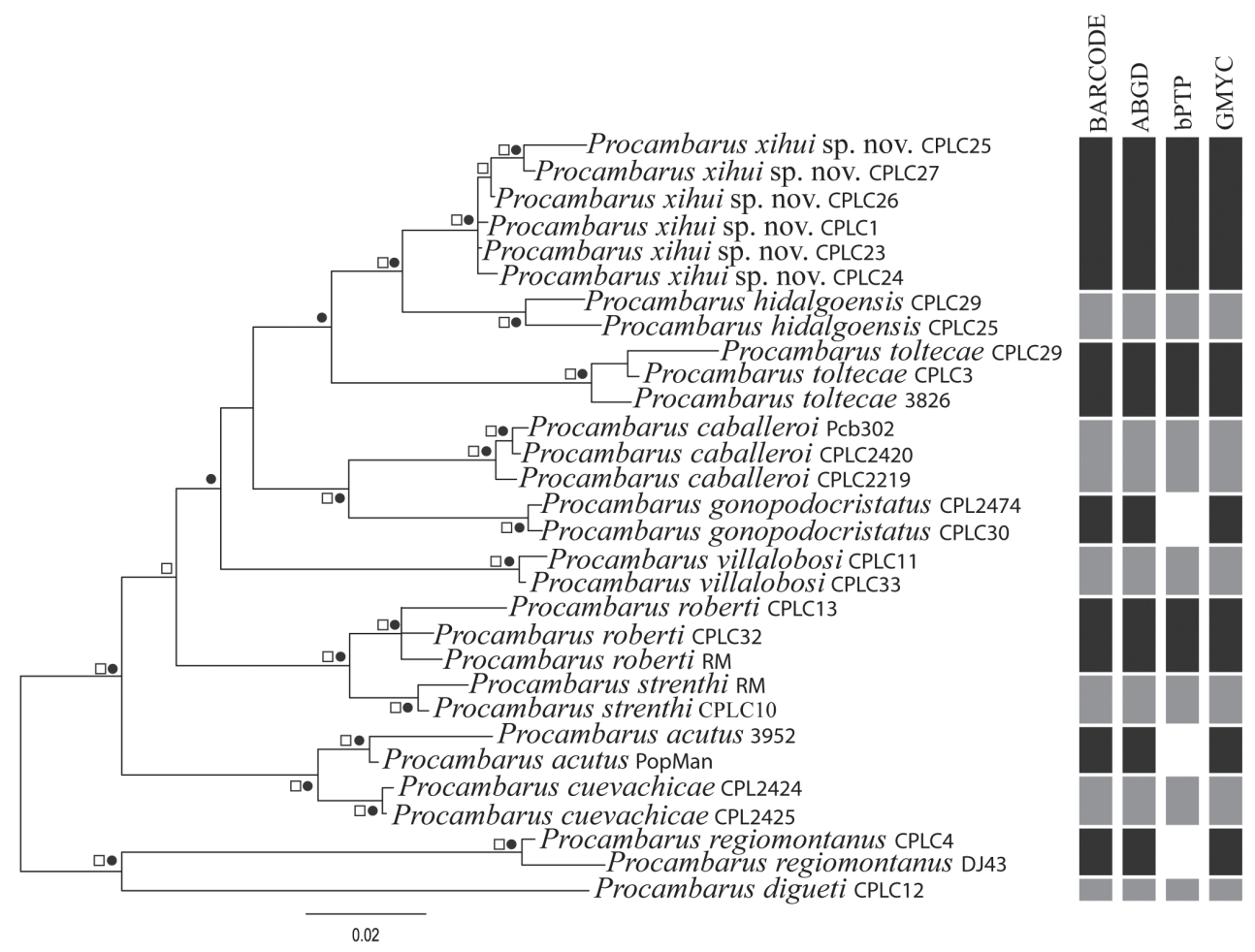

Figure 2. Phylogenetic tree of species analyzed. Codes are referred to in Table 1. BI and ML topologies were completely congruent. Support values of 95 or more (BI) and of 70 or more (ML) are depicted with figures above nodes; circles $=$ posterior probabilities, squares = bootstrap support. At right, recovery of species delimited according to each of the four delimitation criteria used.

of Procambarus ranges from a minimum of $\mathrm{D}_{\mathrm{p}}=3 \%$ for that observed with Procambarus hidalgoensis, and a maximum of $\mathrm{D}_{\mathrm{p}}=10.6 \%$ of with Procambarus regiomontanus (Suppl. material 2: Table S1). Such values are above $\mathrm{D}=1 \%$ and above what is common for between-species distances in crustaceans and crayfish (Fetzner and Crandall 2002; da Silva et al. 2011).

Congruently, the ABGD analysis recovered the undescribed taxon as a separate species from other Procambarus species. The bPTP and GMYC species delimitation analyses separate sequences of such populations as a distinct taxon; GMYC confirms the latter observation as well as the specific status of the remaining Procambarus species (Fig. 2). With the most supported partition scheme of bPTP analysis, all specimens assigned to Procambarus gonopodocristatus, $P$. acutus, and $P$. regiomontanus were not supported as forming one species each; however, the estimated number of species considered by bPTP is between 10 and 26, which includes the scheme of species delimited by the other methods. Bayesian inference and maximum likelihood topologies were congruent (Fig. 2). Topology recovered all species as monophyletic in highly supported clades. One clade included Procambarus acutus and Procambarus cuevachicae; next, a 
clade is recovered containing the remaining species from the Pánuco basin except for Procambarus caballeroi and Procambarus gonopodocristatus, inhabitants of distinct basins south of the Trans Mexican Volcanic Belt (TMVB). Inside this clade, the populations from SGBR were included in a clade in a sister relationship to P. hidalgoensis. These both form a clade close to populations of $P$. toltecae. In the light of these results, a new species is described which includes populations analyzed from the SGBR.

Regarding the conservation assessment, in total, five populations for the species were recorded: populations from Álamos and Camelinas fall into one single 5-10 km² quadrant, and Saldiveña, Río Verdito, and San Juanito each falls into their own $5 \mathrm{~km}^{2}$ quadrant. This resulted in a maximum area of occupancy of $25-35 \mathrm{~km}^{2}$. However, this would be extremely inaccurate, as the available area of habitat (small streams, probably fragmented by large-magnitude creeks) is much more reduced inside each quadrant. Consequently, we consider that a gross estimation of area of occupancy for the species would fall in less than $5 \mathrm{~km}^{2}$. Considering the factors aforementioned, we found a conservation status for Procambarus xibui of Critically Endangered (CR) based on the following criteria: B.2.a (habitat severely fragmented), B.2.b.ii (continuing decline in area of occupancy), and B.2.b.iv (continuing decline in number of locations).

\title{
Systematics
}

\section{Cambaridae Hobbs, 1942 \\ Genus Procambarus Ortmann, 1905}

\author{
Procambarus xibui sp. nov. \\ http://zoobank.org/DCFCDB8F-896F-4071-8CB6-12D6241FE9DB \\ Figures 3, 4, Table 2
}

Material examined. Holotype: male from I (CNCR 35721), $21^{\circ} 8.548^{\prime} \mathrm{N}, 99^{\circ} 17.106^{\prime} \mathrm{W}$, ca 1210 m; stream Los Álamos, Yerbabuena, Jalpan de Serra, Querétaro State, Mexico. A small headwater first-magnitude stream, which keep water in shallow ponds along the year. leg. Heriberto Pedraza Rodríguez, Patricia Ornelas-García, Carlos PedrazaLara, Ma. Guadalupe Lara Zúniga, Guadalupe Gracia, Regina Pedraza Lara, May 22, 2019. Allotype: female (CNCR 35723), same data as holotype. Morphotype: male (CNCR 35722), same data as holotype.

Diagnosis. Body pigmented, eyes well developed. Rostrum lanceolate, concave, without lateral spines; antennal scale width $0.50-0.54 \times$ in its length; areola of moderate width (0.22-0.23 $\times$ wide in length) with 2-4 large punctations in narrowest part; cervical spine absent, single, shallow branchiostegal spine; chela shorter than cephalothorax length, long and thin, length $0.87-0.89 \times$ the length of cephalothorax and $0.28-0.31 \times$ wide than long, narrow-ovate. Dactyl forming a concave profile in mesial margin, palm of chela with scattered tubercles, mesial surface with row of seven or eight tubercles, palm length $0.55-0.66 \times$ in dactyl length; no lateral spines on carapace; postrostral ridges very strong and wide, forming a strong tubercle, provided with longitudinal groove along its 


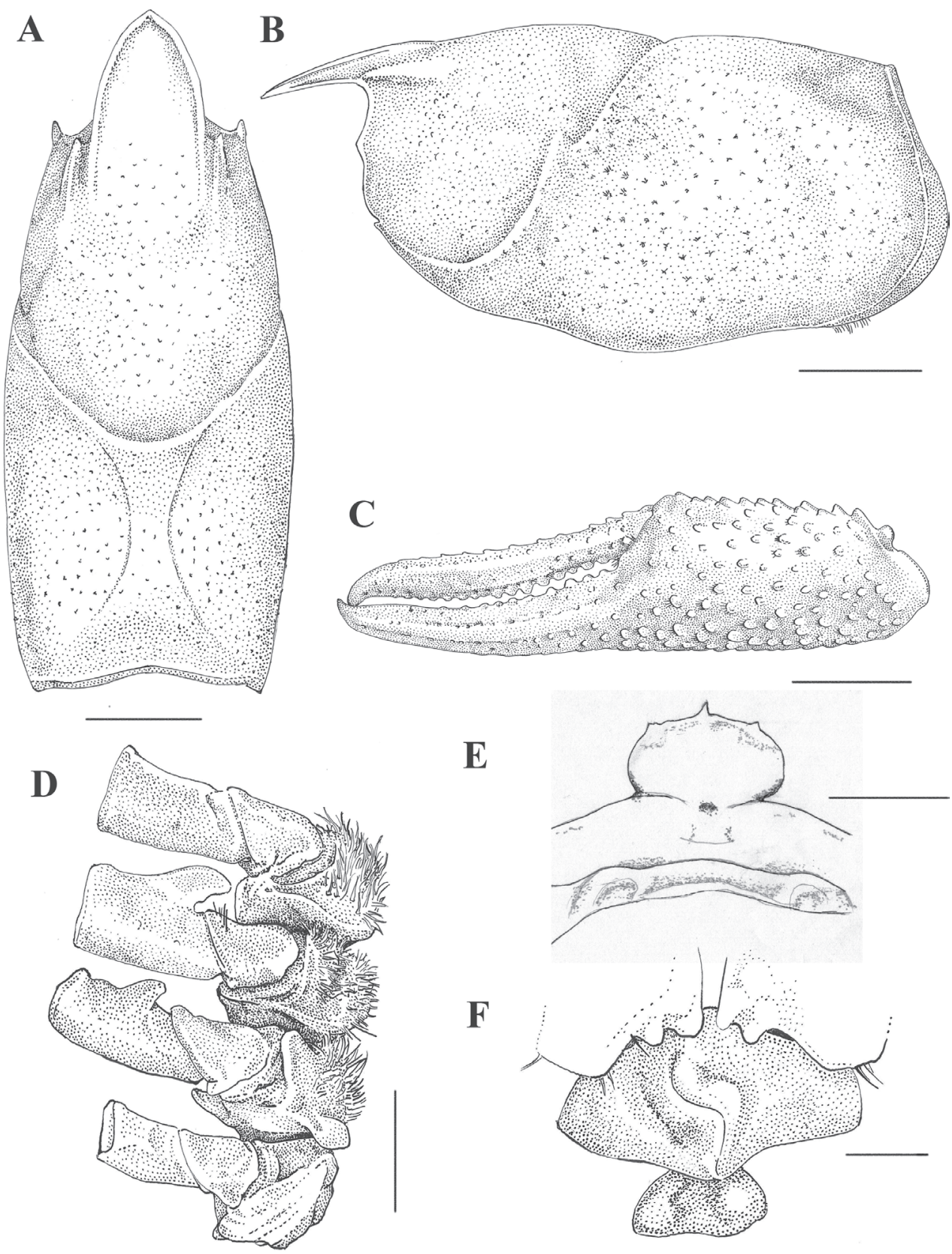

Figure 3. Procambarus xihui. All illustrations from holotype except for $F$ which is from allotype $\mathbf{A}$ dorsal view of cephalothorax $\mathbf{B}$ lateral view of cephalothorax $\mathbf{C}$ lateral view of cheliped $\mathbf{D}$ basal podomeres of second to fifth pereiopods $\mathbf{E}$ Epistome $\mathbf{F}$ caudal view of annulus ventralis. Scale bars: $5 \mathrm{~mm}(\mathbf{A}-\mathbf{C}) ; 2 \mathrm{~mm}$ (D-F).

laterodorsal margin, its apical extreme slightly overreaching carapace surface, not forming evident apical spine. Male with hooks on ischiopodites of the third and fourth pairs of pereiopods, those on third ischiopodite extending beyond basioischial articulation. 
First pair of pleopods slightly asymmetrical, reaching coxopodite of third pereiopod, with shoulder on cephalic margin beginning at distal fifth; a row of setae from base to second third of pleopod, a second row of setae along mesial surface starting at midlength and third row of setae along mesial surface starting on last quart and extending laterally to base of terminal processes, where it forms a tuft of plumose setae; mesial process spiniform, directed caudally and slightly mesially, cephalic process spiniform, acute, hood-like, directed caudomedial, upon central projection and hidden beneath apical tuft; central projection corneous, lamellate, hood-like, tip decidedly projecting mesially, forming a concave blade-like structure, distally folded in mesial direction and reaching beyond the remaining terminal elements; caudal process corneous, crest-like, running on caudomesial surface of pleopod tip, along longitudinal pleopod axis, mesiodistally directed, forming a lateral side of the concavity formed distally by the central projection, reaching bellow point of mesial process position in lateral view.

Preanular plate with strong tubercles in caudal margin, and with setae along its margin, both well projecting over annulus cephalic area. Annulus ventralis rather fusiform, with depression along median surface and sinus in shallow Z-shape. Endopodite and exopodite of uropods with strong distolateral spines and median ridge ending in small spine, not reaching endopodite margin.

Description of holotypic male, Form I. (Figs 3, 4, Table 2). Body pigmented, eyes well developed. Body subovate, abdomen narrower than thorax. At cervical groove carapace slightly higher than wide $(0.99 \times$ height $)$. Areola moderate in width $(0.22 \times$ length) with three or four punctations in narrowest part; length of areola ca. $0.32 \times$ that of entire carapace length. Rostrum lanceolate, dorsally excavated, reaching distal third of second basal segment of antennule, its width $0.69 \times$ in length; margins raised slightly thickened, acumen not sharped, dorsal surface of rostrum punctuated at its base, row of setiferous punctations along base of marginal ridges, subrostral ridges poorly developed, and not evident from dorsal view.

Postrostral ridges conspicuous and wide, forming a strong tubercle, provided with longitudinal groove along its laterodorsal side, its apical edge slightly overreaching carapace surface, not forming evident apical spine. Suborbital angle obtuse, one branchiostegal spine present. Surface of the carapace deeply punctuate.

Epistome broadly triangular, subsymmetrical, with cephalomedian projection well defined. Antennule with ventral spine on basal segment well developed. Antennal scale width $0.5 \times$ its length, maximum width at ca. $0.5 \times$ length, with a ridge along lateral margin ending in a strong spine.

Chela long and thin, $0.89 \times$ the length of carapace and $0.31 \times$ wide as long, narrow-ovate, dactyl forming a concave profile in mesial margin. Chela scattered with numerous setose tubercles and crowded with numerous denticles. Mesial margin of palm with row of seven tubercles, opposable sides of both fingers with strong tubercles, seven stronger on proximal half of dactyl. Fingers gaping along their length. Lateral margin of dactyl with weak ridge of acute tubercles proximally and punctations distally. Tip of fingers forming strong pencils. Opposable margin of fixed finger with four tubercles on basal one-quarter and five punctations along second and third distal quarters. 
Table 2. Measurements of types. Morphometric measurements ( $\mathrm{mm})$ of holotype, allotype, and morphotype of P. xihui sp. nov.

\begin{tabular}{lccc}
\hline \multicolumn{1}{c}{ Measurements } & Holotype & Allotype & Morphotype \\
\hline Total Length (TL) & 59.80 & 61.41 & 65.68 \\
Cephalothorax & & & 32.15 \\
Length (CL) & 28.89 & 28.99 & 15.63 \\
Height (CH) & 13.91 & 14.11 & 15.26 \\
Width (CW) & 13.71 & 13.99 & 21.29 \\
Cephalon length (CEL) & 18.95 & 19.75 & 13.21 \\
Abdomen width (AW) & 12.08 & 11.82 & \\
Rostrum & & & 8.60 \\
Length (RL) & 7.26 & 7.18 & 5.65 \\
Width (RW) & 4.85 & 5.59 & 1.77 \\
Acumen length (AL) & 1.39 & 1.03 & 6.86 \\
Antennal scale length (ASL) & 6.11 & 6.41 & 27.82 \\
Cheliped & & & 7.84 \\
Chela length (CHL) & 25.75 & 19.22 & 16.01 \\
Chela width (CHW) & 8.02 & 5.98 & 8.81 \\
Dactyl length (DL) & 14.50 & 11.30 & 13.32 \\
Palm length (PL) & 9.56 & 7.12 & 10.56 \\
Merus length (ML) & 13.13 & 11.38 & 2.51 \\
Areola & & & 8.79 \\
Areola width (ARW) & 9.12 & 2.05 & \\
Areola length (ARL) & 2.00 & & \\
\hline
\end{tabular}

Table 3.Variability parameters of analyzed gene fragments and the most accurate substitution models.

\begin{tabular}{|c|c|c|c|c|c|}
\hline Gene & Primers* & bp & V & PI & Model $^{* *}$ \\
\hline \multirow[t]{2}{*}{$16 \mathrm{~S}$} & 1471 & 559 & 169 & 82 & $\mathrm{GTR}+\mathrm{G}$ \\
\hline & $16 S-1472$ & & & & \\
\hline \multirow[t]{2}{*}{$12 S$} & $12 \mathrm{sf}$ & 397 & 71 & 51 & $\mathrm{GTR}+\mathrm{I}+\mathrm{G}$ \\
\hline & $12 \mathrm{sr}$ & & & & \\
\hline \multirow[t]{2}{*}{ COI } & ORCO1F & 1506 & 221 & 138 & $\mathrm{GTR}+\mathrm{I}+\mathrm{G}$ \\
\hline & ORCO1R & & & & \\
\hline
\end{tabular}

bp = length in base pairs; V = variable sites; PI = parsimony informative sites; ${ }^{*}$ amplification conditions followed Pedraza-Lara et al. $2012 ;{ }^{* *}$ most appropriate substitution model selected using Partition Finder 2.

Width of carpus of first pereiopod ca. $0.63 \times$ in its length. Merus length $0.45 \times$ in cephalothorax length, with scattered punctations in lateral surface, two rows of spike-like tubercles on mesial surface, stronger at distal half, apical spine present. Hooks on ischiopodites of third and fourth pereiopods, former well exceeding basioischial articulation, latter reaching it. Bases of coxopodites of fourth and fifth pereiopods with caudomesial boss projection, the former extending on wide prominence on caudoventrally surface, caudomedial oriented, setose around margin, the latter blade-like, mesially oriented, bare.

First pleopods as described in diagnosis. Abdomen slightly narrower than carapace, width $0.88 \times$ in cephalothorax width. Protopodite of uropods with distolateral spines, endopodite and exopodite with strong distolateral spines and median ridge ending in small spine, not reaching endopodite margin. Dorsal side of telson with one median spine on each caudolateral corner.

Description of allotypic female. (Fig. 3, Table 2). Differing from holotype in following respects: areola of moderate width $(0.23 \times$ length $)$ with two or three 


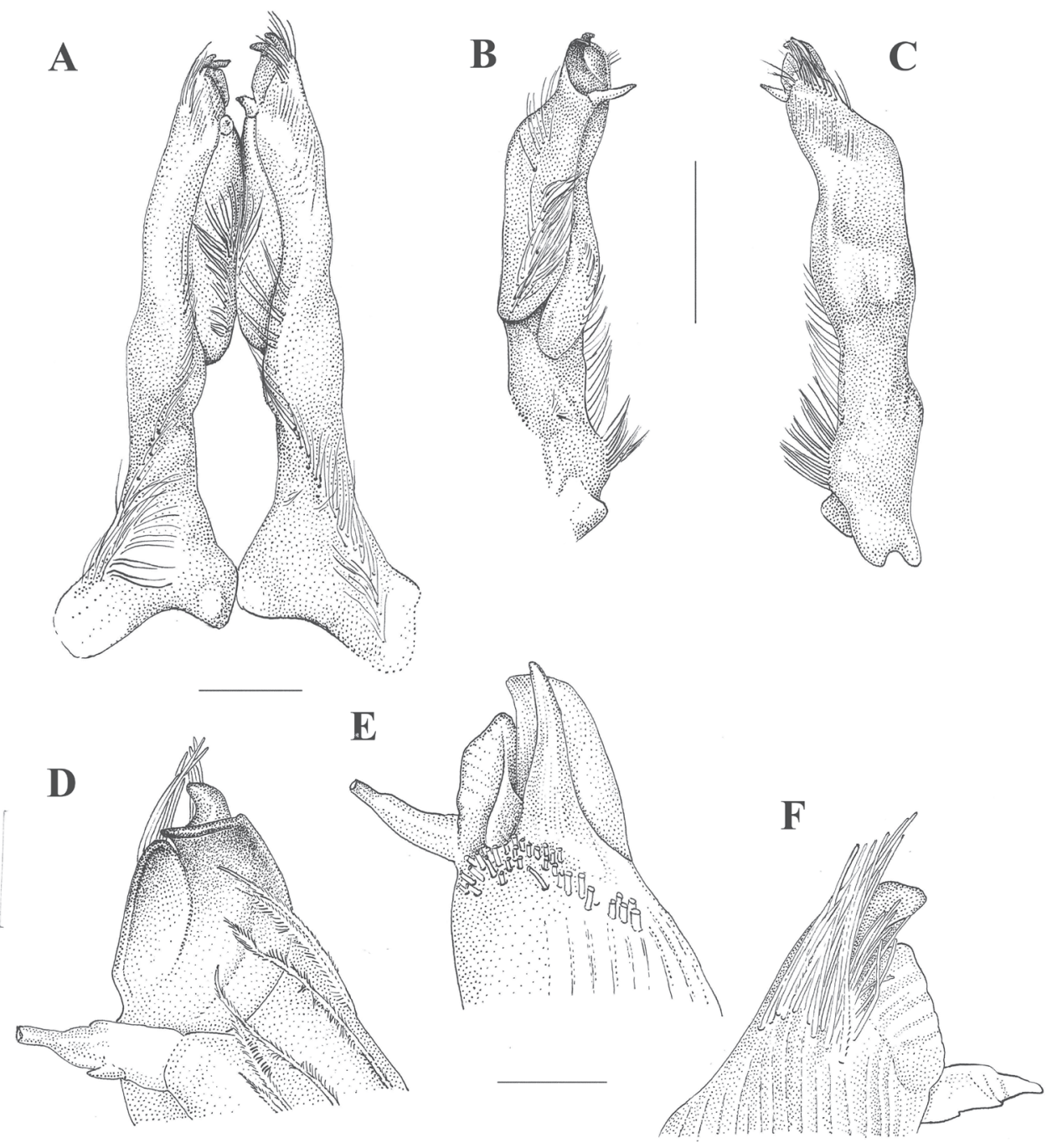

Figure 4. Procambarus xihui, holotype A caudal view of the first pair of pleopods $\mathbf{B}$ mesial view of left gonopod $\mathbf{C}$ lateral view of left gonopod $\mathbf{D}$ detail of apex, mesial view $\mathbf{E}$ detail of apex, latero-cephalic view $\mathbf{F}$ detail of apex, lateral view. Scale bars: $2 \mathrm{~mm}(\mathbf{A}) ; 0.5 \mathrm{~mm}(\mathbf{B}, \mathbf{C}) ; 0.1 \mathrm{~mm}(\mathbf{D}-\mathbf{F})$.

punctations in narrowest part, areola length $0.3 \times$ carapace length. Rostrum wide ( $0.78 \times$ rostrum length).

Shorter and smaller chela, $0.66 \times$ length of carapace and width $0.31 \times$ length, mesial profile of dactyl straight. Four strong tubercles on proximal half of opposable side of dactyl. Two conspicuous tubercles on opposable side of fixed finger, one on distal third. Width of carpus of first pereiopod ca. $0.63 \times$ its length. Shorter merus, $0.39 \times$ cephalothorax length. Left dactyl abnormally small, shorter than fixed finger. 
No hooks on ischiopodites of pereiopods. Caudomesial boss only evident on fifth coxopodite, mesially projected.

Annulus ventralis as described in diagnosis (Fig. 3). First pleopods uniramous, reaching cephalic region of annulus ventralis when abdomen is flexed.

Description of morphotypic male, form II. (Table 2). Differing from holotype in the following respects: areola of moderate width $(0.24 \times$ length $)$ with punctations (two or three in narrowest part).

Left chela $0.87 \times$ the length of cephalothorax and width $0.28 \times$ in its length, mesial surface of chela with a row of ten tubercles, palm $0.55 \times$ in dactyl length. Right chela abnormally smaller. Opposable side of dactyl with five stronger tubercles on proximal side, lateral margin of dactyl with ridge of punctations. Opposable margin of fixed finger with five tubercles on basal quarter, two of them stronger, and punctate along distal half.

Carpus of first pereiopod ca. $1.35 \times$ longer than wide. Shorter merus $(0.41 \times$ cephalothorax length). Shallow hooks on ischiopodites of third and fourth pereiopods, the former longer, none exceeding basioischial articulation.

Terminal elements of first pleopods not stylized, certain incipient development in mesial process and central projection, the latter together with caudal and cephalic processes mesially oriented.

The new species depicts certain variability in coloration among populations, but most individuals show a general brownish body background with lighter scattered spots along thorax and abdomen (Fig. 5). For most individuals, the chela is brown to reddish, with scattered darker or yellowish punctations. Color become lighter to the base of pereiopods. In some individuals, a diffuse darker band is visible on the sides of thorax, which become darker posteriorly, but it is not apparent in others.

Etymology. The specific epithet -xihui comes from the term used by natives from the region, (also known as the Pame people), to refer to themselves. The term also means 'indigenous' in the Pame language.

Phylogenetic relationships and remarks. Except for Procambarus digueti and P. regiomontanus, which are clearly distinctive among the crayfish fauna of Mexico and used here as outgroups, the new species shares some traits with the remaining species included, most of them inhabiting the Pánuco River basin. Among those are the possession of hooks on the ischiopodites of third and fourth pereiopods and the first pair of pleopods reaching the coxa of third pereiopods. However, the new species can be readily distinguished from two other species included inhabiting the Pánuco basin, $P$. strenthi and $P$. roberti, based in the following characters (among others): in $P$. roberti, the first pleopods are asymmetrical and lack a cephalic shoulder, and it possess a subtriangular, laterally grooved caudal process abutting the caudal base of central projection, which is notably more reduced than the shown by $P$. xihui. In $P$. strenthi, the first pleopods of the male form I are also strongly asymmetrical, bearing a strong angular shoulder in the cephalic surface, a cephalic process broad and lamellate, a dentiform central projection and a smaller subtriangular caudal process. 


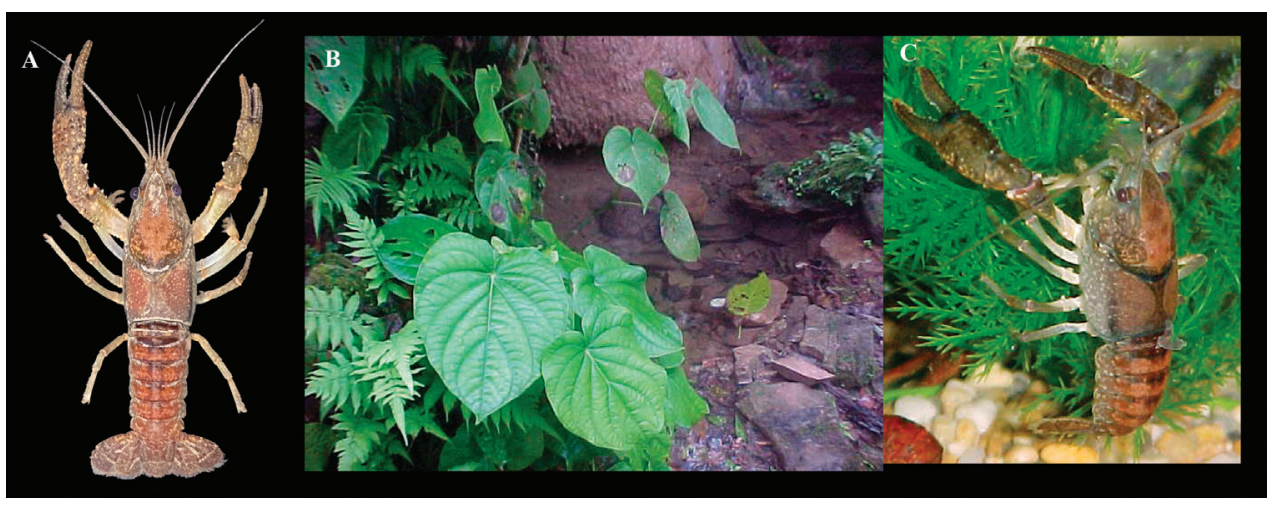

Figure 5. Procambarus xibui $\mathbf{A}$ photograph of form I male alive showing coloration $\mathbf{B}$ general habitat in type locality $\mathbf{C}$ photograph of live specimen in aquarium. Photographs by CPL.

More specifically, the new species is morphologically related to a group of species placed in the subgenus Ortmannicus by Hobbs (1972), although subgeneric groupings in Procambarus have not been recognized recently (Crandall and De Grave 2017). Still, such grouping allows us to identify some morphological similarities among $P$. xihui and the species morphologically most like it. Such species are $P$. acutus, $P$. caballeroi, $P$. cuevachicae, $P$. gonopodocristatus, $P$. hidalgoensis, $P$. toltecae, and $P$. villalobosi. Several traits are shared among the new species and the remaining Mexican species assigned to Ortmannicus sensu Hobbs (1972) such as the lack of caudal knob. In general, the new species can readily be distinguished from the remaining species by the configuration of terminal elements of the first pair of pleopods. In addition, it can be distinguished from $P$. acutus and $P$. cuevachicae as these show a distally directed mesial process, a cephalic process somewhat rounded distally, an acute caudal process, a somewhat twisted central projection, and an almost obliterated areola. $P$. acutus and $P$. cuevachicae also lack a cephalic shoulder in the first pleopod. The new species can be readily separated from $P$. villalobosi, among several other traits, by the conspicuous arrangement of all apical elements of the first pleopod in P. villalobosi, which has a singularly long mesial process far exceeding the other elements caudally.

Among other differences, the new species can be separated from $P$. caballeroi as the latter possess a wider rostrum, a laminated, laterally flattened cephalic process, a crest-like caudal process whose apex ends in a spine-like structure that is caudodistally directed. Among the main differences with P. gonopodocristatus are that the latter possesses a caudal process in the form of a long blade arced along the caudolateral surface, when in $P$. xibui this process is longer and situated along the caudomesial surface of the pleopod. Procambarus caballeroi and P. gonopodocristatus inhabit other river basins, south of the TMVB. The two species that most resemble P. xihui are P. toltecae and P. hidalgoensis.

The new species can easily be differentiated from $P$. toltecae because the latter shows a different arrangement of the terminal elements of the first pleopod: most conspicuous are the caudal orientations of the cephalic and caudal processes as well as the central 
projection, the latter two forming a triangular projection which extends in caudally and forms a right angle to the longitudinal axis of the appendix. In $P$. toltecae, the central projection is the longest among the related species, while in $P$. xibui, the three most apical elements are directed mesially and the caudal process is blade-like and runs along the mesial side of the pleopod. We find that the new species is most similar to $P$. hidalgoensis, from which, however, clear differences can be noticed. In the latter, the mesial process is latero-distally oriented, while in P. xihui its orientation is caudal and slightly mesial; both show a central projection that is corneous and flattened, but its division in two elements in $P$. hidalgoensis is clear, one larger and distally projected and the other shorter, straight, and mesially projected, while in $P$. xibui the two elements are fused and no clear delimitation exists between them unless observed on electron microscopy; they form one concave blade-like structure, distally folded in a mesial direction. The caudal process is laminated in both species, but in P. hidalgoensis it is located mesiocaudally to central projection, while in $P$. xibui it is more laterally located, becoming the lateral side of the concavity formed by the central projection, also mesially directed. In vivo, a distinctive red coloration was recorded in the male form I of $P$. hidalgoensis with a contrasting blackish stripe running laterally of cephalothorax. In P. xihui, a dark stripe can be present, but it does not contrast as the body color is brownish (Fig. 5).

The phylogenetic analysis partially agrees with deductions from morphological similarities. The new species is grouped in a clade with $P$. hidalgoensis: these two species inhabit small, first-order springs of the Pánuco basin, although $P$. xihui inhabits higher altitude parts of three different sub-basins (between 1,000 $\mathrm{m}$ and ca. $1,200 \mathrm{~m}$ ): the Jalpan River (later a tributary of the Santa María sub-basin), the Tancuilín sub-basin, and Extoraz sub-basin (both tributaries of the Moctezuma River). On the other side, P. hidalgoensis inhabits similar habitats (at an altitude of 1,485 m) but from the Río Hule sub-basin, a southern component of the Moctezuma sub-basin. This clade is grouped with $P$. toltecae, which inhabits much lower altitudes (here collected from $273 \mathrm{~m}$ ). Similarly, the Pánuco system is inhabited by the remaining species here included except for $P$. digueti and $P$. regiomontanus, but most of them are from distinct sub-basins or altitudes. Results shown here support that this region is a depositary of distinct clades of crayfish diversity in Mexico, which possibly reflects a complex biogeographic history for the genus in northeast Mexico, from which P. xihui is one additional component. Additional phylogenetic and biogeographic inferences are surely complex and beyond the scope of the present manuscript and will be treated in further work.

Habitat and conservation notes. The new species inhabits an entirely included area in the SGBR. With certain variation among populations, habitats are headwater stream ecosystems, less than 1.5 meters wide, showing surface water intermittently along their course for most of the year, especially in small ponds that are $0.5-3 \mathrm{~m}$ wide with reduced water flow (Fig. 5). These are very sensitive habitats, reduced in area and characterized by a high quality of riparian vegetation and pristine water conditions (Meyer et al. 2007). During the rainy season they can occasionally join the next water course, where crayfish populations have not been found; consequently it is possible 
that a high degree of habitat fragmentation can exist between locations. They are characterized by oligotrophic water conditions (elevated oxygen concentration, low temperatures and low nutrients) and substrates composed of bedrock, rocks, pebbles, cobbles, leaf litter, tree branches (Pedraza-Lara et al. 2004), and other elements that provide shadow, refuge, and high habitat heterogeneity. The riparian vegetation, rocks, and gravels are of special importance for crayfish survival since they are nocturnal and usually spend most of the day hidden in these substrates.

The characteristic physical and chemical parameters of their habitats are temperatures between 20 and $28{ }^{\circ} \mathrm{C}$, dissolved oxygen content between 8 and $12 \mathrm{mg} \mathrm{l}^{-1}$,

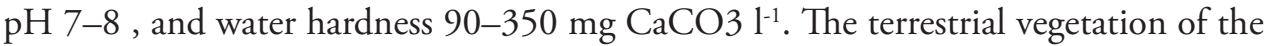
riverside where the crayfish populations were found is composed by riparian vegetation of Platanus mexicana, Taxodium mucronatum, and Salix species.

Headwater streams might be more vulnerable to disturbances in the surrounding catchment than other aquatic habitats, which relate to a higher risk of biodiversity loss (Lowe and Likens 2005). Populations inhabiting headwater stream ecosystems are especially sensitive to rainy conditions, as short and severe periods of drought could represent a high risk of extinction of their populations (Boulton 2003). The last decade in central and northern Mexico has been dryer than preceding decades (Seager et al. 2009): the most severe drought recorded from the BRSG was during 2010-2015, with the year 2012 being the most intense (Mendoza-Villa et al. 2018). Climatic predictions at a regional scale indicate that naturally occurring sub-decadal droughts will be made more frequent and widespread by anthropogenic climate change (Seager et al. 2009). Locally, water from the localities of the new species is intensively used for human consumption, crops, and livestock activities. Impacts driven by climate change are expected to be substantial on headwater streams ecosystems, which makes diagnosing and planning for conservation an urgent task (Durance and Ormerod 2007). From this perspective, the conservation of the headwaters of the rivers, as well as the maintenance of seasonal water regimes is of utmost importance to preserve endemic species, especially those that have very narrow distributions, such as $P$. xihui. Human actions also induce climate change to be faster in these areas, affecting the general ecological functioning of the Sierra and with it, also human activities (pers. obs.).

Collections for populations from the new species were made in the year 2002 and attempted in 2019, covering nearly 20 years. The climatic conditions and intense use of water described above has probably been related to the dramatic change observed by us at the visited sites, in which three of the five streams were almost dry or completely modified. In June 2019, an attempt to collect with the same sampling effort used in 2002 was carried out at all sites. We failed to find any crayfish at Las Camelinas, Saldiveña, and San Juanito, and in the remainder, crayfish were at much lower abundances than previously recorded. Additionally, several mass mortalities of crayfish were recorded from some sites, produced by the use of pesticides in crops surrounding the small streams.

As seen by their location, most populations were found in separated streams which were not in contact with each other for most of the year or even for several years. Most of individuals were found in such small populations and face situations 
of high dryness, in which they are limited to a small number of pools, representing a high risk of local extinctions. If crayfish diversity is one of the most endangered among freshwater fauna in the world (Richman et al. 2015), cambarids have the most threatened species in Mexico concerning freshwater Crustacea (Alvarez and Villalobos 2016). The new species is an especially sensitive case derived from its peculiar habitat and narrow distribution ranges, which emphasizes an urgent need to design and fulfill conservation measures in the short term to avoid extinction of most of its populations. Consequently, efforts to include the species into the Mexican law NOM059-SEMARNAT-2010: Environmental Protection-Native species of Mexico of wild flora and fauna will be conducted.

\section{Acknowledgements}

We thank Patricia Ornelas, Heriberto Pedraza R., Ma. Guadalupe Lara, Sandra Pedraza, Heriberto Pedraza L., Regina Pedraza, and Gael Pedraza for their guidance and help collecting several of the populations. Halan Ortíz-Herrera made took some of the measurements, Aslam Narváez made the illustrations. This work was financed by project 257263 granted by CONACyT and project IA205020 by DGAPA - PAPIIT, UNAM both granted to the first author. This work was also supported by a postdoctoral fellowship to VJB by DGAPA, UNAM. Micrographs were taken by Berenit Mendoza-Garfias at the Lab of Electron Microscopy of Biology Institute, UNAM. Some lab work was assisted by Christian Cárdenas Monroy. Some species were collected with the help of Leonardo García-Vázquez, Stephany Rodríguez, Sharif Rodríguez, and Carlos Garita; some populations from SGBR were sampled on previous occasions with the help of Alfredo Morales-Ortíz and Carlos Ramírez.

\section{References}

Alvarez F, Villalobos JL (2016) Freshwater decapod diversity and conservation in Mexico. In: Kawai T, Cumberlidge N (Eds) A global overview of the conservation of freshwater decapod crustaceans. Springer, Cham, 237-266. https://doi.org/10.1007/978-3-319-42527-6_8

Bezerra F, Rudolph E, Pedraza-Lara C (2020) Decapoda: Astacidea. In: Damborenea C, Rogers C, Thorp JH (Eds) Thorp and Covich's Freshwater Invertebrates. Volume V. Keys to Neotropical and Antarctic Fauna. Elsevier, London, 874-901.

Bouckaert R, Heled J, Kühnert D, Vaughan T, Wu C-H, Xie D, Suchard MA, Rambaut A, Drummond AJ (2014) BEAST 2: A Software Platform for Bayesian Evolutionary Analysis. PLoS Computational Biology 10: e1003537. https://doi.org/10.1371/journal. pcbi. 1003537

Boulton AJ (2003) Parallels and contrasts in the effects of drought on stream macroinvertebrate assemblages. Freshwater Biology 48: 1173-1185. https://doi.org/10.1046/j.13652427.2003.01084.x 
Crandall KA, De Grave S (2017) An updated classification of the freshwater crayfishes (Decapoda: Astacidea) of the world, with a complete species list. Journal of Crustacean Biology 37: 615-653. https://doi.org/10.1093/jcbiol/rux070

Donoghue MJ (1985) A critique of the biological species concept and recommendations for a phylogenetic alternative. Bryologist: 172-181. https://doi.org/10.2307/3243026

Durance I, Ormerod SJ (2007) Climate change effects on upland stream macroinvertebrates over a 25-year period. Global change biology 13: 942-957. https://doi.org/10.1111/ j.1365-2486.2007.01340.x

Fetzner JJ, Crandall KA (2002) Genetic variation. In: Holdich DM (Ed.) Biology of freshwater crayfish. Blackwell Science, Oxford, 291-326.

Gutiérrez-Yurrita PJ (2014) Holistic management of temporary watersheds in Central Mexico: an improved easy mathematical model for decision-makers. International Journal of Ecology and Environmental Sciences 40: 95-110.

Gutiérrez-Yurrita PJ, Morales-Ortiz A, Oviedo A, Ramírez-Pérez C (2002) Distribution, spread, habitat characterization and conservation of freshwater crayfish species (Cambaridae) in Querétaro, Central México. Freshwater Crayfish 13: 349-358.

Hebert PDN, Cywinska A, Ball SL, DeWaard JR (2003) Biological identifications through DNA barcodes. Proceedings of the Royal Society B - Biological Sciences 270: 313-321. https://doi.org/10.1098/rspb.2002.2218

Hobbs HHJ (1941) A new crayfish from San Luis Potosi, Mexico (Decapoda, Astacidae). Zoologica 26: 1-4. https://doi.org/10.2307/2420759

Hobbs HHJ (1943) Two new crayfishes of the genus Procambarus from Mexico (Decapoda, Astacidae). Lloydia 6: 198-206.

Hobbs HHJ (1972a) Biota of Freshwater Ecosystems, Identification Manual no. 9, Crayfishes (Astacidae) of North and Middle America. EPA project \# 18050 ELD.

Hobbs HHJ (1972b) The subgenera of the crayfish genus Procambarus (Decapoda, Astacidae). Smithsonian Contributions to Zoology 117: 1-22. https://doi.org/10.5479/ si.00810282.117

Hobbs HHJ (1977) A new crayfish (Decapoda: Cambaridae) from San Luis Potosí, Mexico. Proceedings of the Biological Society of Washington 90: 412-419.

IUCN Standards and Petitions Committee (2019) Guidelines for using the International Union for Conservation of Nature Red List categories and criteria.

Kumar S, Stecher G, Li M, Knyaz C, Tamura K (2018) MEGA X: Molecular evolutionary genetics analysis across computing platforms. Molecular Biology and Evolution 35: $1547-$ 1549. https://doi.org/10.1093/molbev/msy096

Lanfear R, Frandsen PB, Wright AM, Senfeld T, Calcott B (2017) PartitionFinder 2: New methods for selecting partitioned models of evolution for molecular and morphological phylogenetic analyses. Molecular Biology and Evolution 34: 772-773. https://doi. org/10.1093/molbev/msw260

López-Mejía M, Alvarez F, Mejía-Ortíz LM (2005) Procambarus (Ortmannicus) hidalgoensis (Crustacea: Decapoda: Cambaridae), a new species of crayfish from Mexico. Proceedings of the Biological Society of Washington 118: 558-565. https://doi.org/10.2988/0006-324X( 2005)118[558:POHCDC]2.0.CO;2 
Lowe WH, Likens GE (2005) Moving headwater streams to the head of the class. BioScience 55: 196-197. https://doi.org/10.1641/0006-3568(2005)055[0196:MHSTTH]2.0.CO;2 Matzen da Silva J, Creer S, Dos Santos A, Costa AC, Cunha MR, Costa FO, Carvalho GR (2011) Systematic and evolutionary insights derived from mtDNA COI barcode diversity in the Decapoda (Crustacea: Malacostraca). PLoS ONE 6(5): e19449. https://doi. org/10.1371/journal.pone.0019449

Mendoza-Villa ON, Cambrón-Sandoval VH, Cerano-Paredes J, Cervantes-Martínez R, SotoCorrea JC (2018) Reconstruction of historical precipitation (1877-2014) for the southwest of the Sierra Gorda Biosphere Reserve, Querétaro, Mexico. Revista Chapingo Serie Ciencias Forestales 24: 371-386. https://doi.org/10.5154/r.rchscfa.2018.01.008

Meyer JL, Strayer DL, Wallace JB, Eggert SL, Helfman GS, Leonard NE (2007) The contribution of headwater streams to biodiversity in river networks 1. JAWRA Journal of the American Water Resources Association 43: 86-103. https://doi.org/10.1111/j.1752-1688.2007.00008.x

Pedraza-Lara C, Doadrio I (2015) A new species of dwarf crayfish (Decapoda: Cambaridae) from central México, as supported by morphological and genetic evidence. Zootaxa 3963: 583-594. https://doi.org/10.11646/zootaxa.3963.4.5

Pedraza-Lara C, López-Romero A, Gutiérrez-Yurrita PJ (2004) Preliminary studies concerning phenotype and molecular differences among freshwater crayfish from the sub-genus Procambarus (Ortmannicus) in Sierra Gorda Biosphere Reserve, Mexico. Freshwater crayfish 14: 129-139.

Pedraza-Lara C, Doadrio I, Breinholt JW, Crandall KA (2012) Phylogeny and Evolutionary Patterns in the Dwarf Crayfish Subfamily (Decapoda: Cambarellinae). Castresana J (Ed.) PLoS ONE 7: e48233. https://doi.org/10.1371/journal.pone.0048233

Pons J, Kamoun S, Barraclough TG, Duran DP, Vogler AP, Cardoso A, Sumlin WD, Gomez-Zurita J, Hazell S (2006) Sequence-Based Species Delimitation for the DNA Taxonomy of Undescribed Insects. Systematic Biology 55: 595-609. https://doi. org/10.1080/10635150600852011

Puillandre N, Lambert A, Brouillet S, Achaz G (2012) ABGD, Automatic Barcode Gap Discovery for primary species delimitation. Molecular Ecology 21: 1864-1877. https://doi. org/10.1111/j.1365-294X.2011.05239.x

Rambaut A, Drummond AJ, Xie D, Baele G, Suchard MA (2018) Posterior summarization in Bayesian phylogenetics using Tracer 1.7. Systematic biology 67(5): 901-904. https://doi. org/10.1093/sysbio/syy032

Richman NI, Bohm M, Adams SB, Alvarez F, Bergey EA, Bunn JJS, Burnham Q, Cordeiro J, Coughran J, Crandall KA, Dawkins KL, DiStefano RJ, Doran NE, Edsman L, Eversole AG, Fureder L, Furse JM, Gherardi F, Hamr P, Holdich DM, Horwitz P, Johnston K, Jones CM, Jones JPG, Jones RL, Jones TG, Kawai T, Lawler S, Lopez-Mejia M, Miller RM, Pedraza-Lara C, Reynolds JD, Richardson AMM, Schultz MB, Schuster GA, Sibley PJ, Souty-Grosset C, Taylor CA, Thoma RF, Walls J, Walsh TS, Collen B (2015) Multiple drivers of decline in the global status of freshwater crayfish (Decapoda: Astacidea). Philosophical Transactions of the Royal Society B - Biological Sciences 370: 20140060 20140060. https://doi.org/10.1098/rstb.2014.0060

Ronquist F, Huelsenbeck JP (2003) MrBayes 3: Bayesian phylogenetic inference under mixed models. Bioinformatics 19: 1572-1574. https://doi.org/10.1093/bioinformatics/btg180 
Rosen DE (1979) Fishes from the uplands and intermontane basins of Guatemala: revisionary studies and comparative geography. Bulletin of the AMNH vol. 162, article 5.

Sambrook J, Fritsch EF, Maniatis T (1989) Molecular cloning: a laboratory manual, $2^{\text {nd }}$ edn. Cold Springs Harbor Laboratory Press, New York, 1626 pp.

Seager R, Ting M, Davis M, Cane M, Naik N, Nakamura J, Li C, Cook E, Stahle DW (2009) Mexican drought: an observational modeling and tree ring study of variability and climate change. Atmósfera 22: 1-31.

Stamatakis A (2014) RAxML version 8: a tool for phylogenetic analysis and post-analysis of large phylogenies. Bioinformatics (Oxford, England) 30: 1312-1313. https://doi.org/10.1093/ bioinformatics/btu033

Toon A, Finley M, Staples J, Crandall KA (2009) Decapod phylogenetics and molecular evolution. In: Martin JW, Crandall KA, Felder DL (Eds) Decapod crustacean phylogenetics. Taylor and Francis Group, LLC, Boca Raton, FL, 15-29. https://doi.org/10.1201/9781420092592-c2

Villalobos-Figueroa A (1954) Estudios de los cambarinos mexicanos XI. Una nueva subespecie de Procambarus simulans del Edo. de Nuevo León. Anales del Instituto de Biologia, Universidad Nacional Autonoma de Mexico 25: 289-298.

Villalobos A (1944) Estudios de los cambarinos Mexicanos, III. Una especie nueva de Procambarus, Procambarus caballeroi n. sp. Anales del Instituto de Biología, Universidad Nacional Autónoma de México 15: 175-184.

Villalobos A (1955) Cambarinos de la fauna mexicana (Crustacea Decapoda). PhD Tesis. Universidad Nacional Autónoma de México.

Villalobos A (1958) Estudios de los cambarinos mexicanos, XIII. Descripción de una nueva especie de cambarinos del estado de Veracruz (Crustacea, Decapoda). Anales del Instituto de Biologia, Universidad Nacional Autónoma de México 28: 279-288.

Villalobos Figueroa A, Hobbs HHJ (1974) Three new crustaceans from La Media Luna, San Luis Potosí, Mexico. Smithsonian Contributions to Zoology 174: 1-18. https://doi. org/10.5479/si.00810282.174

Zhang J, Kapli P, Pavlidis P, Stamatakis A (2013) A general species delimitation method with applications to phylogenetic placements. Bioinformatics 29: 2869-2876. https://doi. org/10.1093/bioinformatics/btt499

\section{Supplementary material I}

\section{Results of the ABGD, bPTP and GMYC species delimitation analysis}

Authors: Carlos Pedraza-Lara, Pedro Joaquín Gutiérrez-Yurrita, Vladimir Salvador De Jesus-Bonilla

Data type: Delimitation analyses

Copyright notice: This dataset is made available under the Open Database License (http://opendatacommons.org/licenses/odbl/1.0/). The Open Database License $(\mathrm{ODbL})$ is a license agreement intended to allow users to freely share, modify, and use this Dataset while maintaining this same freedom for others, provided that the original source and author(s) are credited.

Link: https://doi.org/10.3897/zookeys.1048.57493.suppl1 


\section{Supplementary material 2}

\section{Table S1}

Authors: Carlos Pedraza-Lara, Pedro Joaquín Gutiérrez-Yurrita, Vladimir Salvador De Jesus-Bonilla

Data type: Genetic distances

Explanation note: Uncorrected $P$-distances for the COI fragment between species included in this study (in bold) and standard error.

Copyright notice: This dataset is made available under the Open Database License (http://opendatacommons.org/licenses/odbl/1.0/). The Open Database License $(\mathrm{ODbL})$ is a license agreement intended to allow users to freely share, modify, and use this Dataset while maintaining this same freedom for others, provided that the original source and author(s) are credited.

Link: https://doi.org/10.3897/zookeys.1048.57493.suppl2 